\title{
Gasserian Meningioma
}

National Cancer Institute

\section{Source}

National Cancer Institute. Gasserian Meningioma. NCI Thesaurus. Code C6779.

A meningioma that affects the trigeminal ganglion. 